\title{
Pengembangan Ekonomi Indonesia Berbasis Wisata Halal
}

\author{
Fitrianto \\ UIN Sunan Kalijaga Yogyakarta \\ fitrianto88@gmail.com
}

\begin{abstract}
This paper describes the development of Indonesian economy based on halal tourism. The tourism sector is Indonesia's mainstay in gaining foreign exchange. Tourism can be used as an engine of economic growth for the country. The Indonesian government targets 20 million foreign tourist visits in 2019. Foreign tourist visits to Indonesia have increased during 2017 to 2018. The Badan Pusat Statistik (BPS) released the number of foreign tourist visits to Indonesia during 2018 to reach 15.81 million or an increase of $12.58 \%$. In 2018, foreign exchange from the tourism sector accounted for US $\$ 17 \mathrm{M}$, an increase of $11.8 \%$. Halal tourism is a tourism concept that matches Islamic values. Indonesia has a great opportunity in developing the halal tourism sector. Bank Indonesia (BI) states that halal tourism also supports the development of Islamic economics. Halal tourism can strengthen the country's economy. In April 2019 Indonesia was ranked first in the category of the world's best halal tourism destinations based on the Global Muslim Travel Index (GMTI) standard.
\end{abstract}

Keywords: Economic, Tourist, Halal Tourism

\section{Abstrak}

Tulisan ini membahas mengenai pengembangan ekonomi Indonesia berbasis wisata halal. Sektor pariwisata menjadi andalan Indonesia untuk memperoleh devisa negara. Pariwisata dapat dijadikan sebagai mesin pertumbuhan ekonomi bagi negara. Pemerintah Indonesia menargetkan 20 juta kunjungan wisatawan mancanegara pada tahun 2019. Kunjungan wisatwan mancanegara ke Indonesia mengalami peningkatan selama tahun 2017 hingga 2018. Badan Pusat Statistik (BPS) merilis jumlah kunjungan wisatawan mancanegara ke Indonesia selama 2018 mencapai 15,81 juta atau mengalami kenaikan sebesar 12,58\%. Pada tahun 2018, devisa dari sektor pariwisata menyumbang sebesar US\$17 M, meningkat sebesar $11,8 \%$. Wisata halal dapat dikatakan sebagai konsep wisata yang sesuai nilai - nilai Islam. Indonesia mempunyai peluang besar di dalam pengembangan sektor wisata halal. Bank Indonesia (BI) menyatakan bahwa wisata halal turut mendukung pengembangan ekonomi syariah. Wisata halal dapat memperkuat perekonomian negara. Pada tahun 2019 Indonesia menempati peringkat pertama kategori destinasi wisata halal terbaik dunia berdasarkan standar Global Travel Muslim Index (GMTI).

Kata Kunci: Ekonomi, Wisatawan, Wisata Halal

\section{PENDAHULUAN}

Menurut UU No 10 Tahun 2009 Pasal 1 ayat 1 tentang Kepariwisataan, Pariwisata adalah berbagai macam kegiatan wisata dan didukung berbagai fasilitas serta layanan yang disediakan oleh masyarakat, pengusaha, Pemerintah, dan Pemerintah Daerah. Sektor pariwisata masih menjadi andalan Indonesia untuk memperoleh devisa negara. Keadaaan alam 
geografis Indonesia menjadikan sektor pariwisata menjadi hal yang sangat penting. Kekayaan sumberdaya alam serta budaya Indonesia mendorong keiinginan pemerintah untuk mengenalkan kekayaan Indonesia kepada dunia luar.

Sektor pariwisata dapat menjadi andalan pemerintah Indonesia untuk dijadikan sebagai mesin pertumbuhan ekonomi bagi negara. Pariwisata merupakan salah satu sektor yang paling cepat menghasilkan pemasukan bagi negara dengan modal yang tidak terlalu besar. UU No 10 Tahun 2009 tentang kepariwisataan menjadi payung hukum bagi pelaku di sektor pariwisata. Pariwisata dapat diandalkan sebagai pemasok devisa bagi negara, terutama dari wisatawan mancanegara.

Dalam meningkatkan sektor pariwisata disuatu daerah, setidaknya harus mengembangkan konsep 3A (Atraksi, Aksesibilitas, dan Amenitas). Atraksi adalah produk utama dari sebuah destinasi yang berkaitan dengan "what to see" dan "what to do". Aksesibilitas adalah sarana dan infrastruktur untuk menuju destinasi wisata, seperti jalan raya, moda transportasi, petunjuk arah dan sebagainya. Amenitas berkaitan dengan ketersediaan sarana akomodasi seperti tempat penginapan, restoran, rest area, tempat ibadah. Apabila ketiga komponen tersebut dapat terpenuhi dengan baik, wisatawan yang berkunjung dapat dipastikan akan merasa nyaman dan kedatangan wisatawan diharapkan akan terus meningkat.

Belum lama ini disebutkan dalam Liputan 6, pemerintah melalui Kementerian Pariwisata RI menargetkan 20 juta kunjungan wisatawan mancanegara ke Indonesia pada tahun 2019. Hal ini bukan tanpa dasar, mengingat sektor pariwisata di Indoenesia menunjukkan peningkatan setiap tahun. Hal ini menunjukkan bahwa sektor pariwisata Indonesia sangat menjanjikan mengingat belum semua sumberdaya yang dimiliki tergarap semuanya.

\section{Gambar 1}

\section{Data Kunjungan Wisatawan Mancanegara 2017 \& 2018}

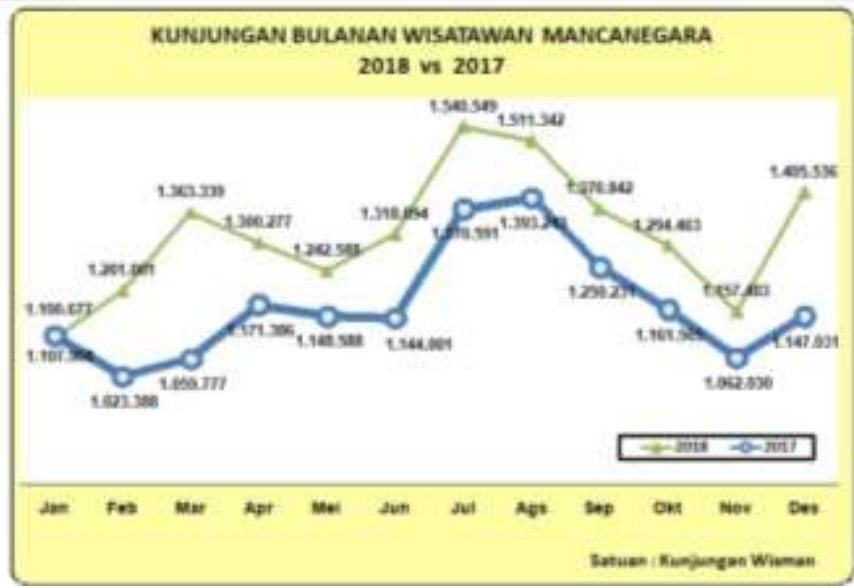

Sumber: Kementerian Pariwisata RI, 2019 
Dari gambar di atas dapat dilihat secara jelas, kunjungan wisatwan mancanegara mengalami peningkatan selama tahun 2017 hingga 2018. Badan Pusat Statistik (BPS) merilis jumlah kunjungan wisatawan mancanegara ke Indonesia selama 2018 mencapai 15,81 juta atau mengalami kenaikan sebesar 12,58 \% dibandingkan pada periode yang sama tahun 2017 berjumlah 14,04 juta kunjungan. Menurut Laporan BPS dalam Kontan selama Desember 2018, total wisatawan mancanegara yang berkunjung ke Indonesia sebanyak 1,41 juta orang atau naik 22,5 \% dibanding Desember 2017 sebanyak 1,15 juta.

Sektor pariwisata juga mempunyai peran besar dalam meningkatkan pemasukan devisa negara. Salah satu kunci penguatan ekonomi Indonesia dari penerimaan devisa adalah peningkatan sektor pariwisata (Maghfira Maulidia, 2019). Devisa adalah sejumlah emas atau valuta asing yang bisa digunakan untuk bertaransaksi pembayaran dengan luar negeri yang diterima dan diakui luas oleh dunia internasional. Adapun devisa sendiri mempunyai fungsi sebagai; alat pembayaran hutang luar negeri, alat transaksi pembayaran ekspor dan impor, alat transaksi pembayaran hubungan dengan luar negeri (misi kedutaan, misi budaya), dan sebagai pendapatan negara. Berdasarkan laporan dari Kementerian Pariwisata RI selama lima tahun terakhir, pendapatan devisa dari sektor pariwisata terus mengalami peningkatan.

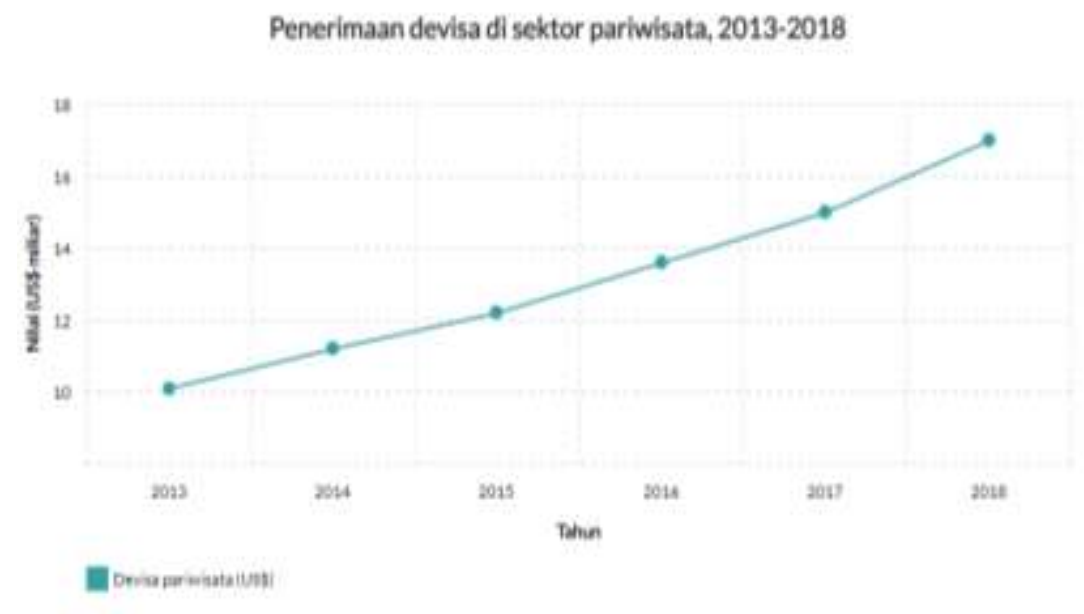

Sumber: Kementerian Pariwitasa RI, 2019

Berdasarkan laporan dari Kementerian Pariwisata RI (Kemenpar), penerimaan devisa pada sektor pariwisata terus meningkat sejak tahun 2013. Pada tahun 2018 yang lalu, devisa menyumbang sebesar US\$17 M, meningkat sebesar 11,8 \% dibandingkan tahun sebelumnya. Kemenpar juga memprediksi, devisa tahun 2019 ditargetkan akan meningkat menjadi US\$ $20 \mathrm{M}$.

Seiring dengan tuntutan keadaan, sektor pariwisata mengalamai perkembangan inovasi termasuk hadirnya tren wisata halal yang semakin gencar dalam beberapa tahun ini. Indonesia sebagai negara mayoritas 
berpenduduk Islam menangkap peluang besar ini untuk lebih mengembangkan potensi di sektor wisata halal. Wisata halal ini mulai berkembang dikarenakan tuntutan gaya hidup seseorang yang gemar berwisata namun tetap menjaga aturan - aturan syariat seperti makanan dan minum halal, penginapan berkonsep syariah. Isitilah wisata halal baru mulai dikenal sejak 2015 ketika sebuah event World Halal Tourism Summit (WHTS) digelar di Abu Dhabi, UAE. Dalam acara tersebut, WHTS berusaha menyadarkan bahwa potensi wisata halal sangatlah besar dan perlu untuk dikembangkan. Menurut Dinas Kebudayaan dan Pariwisata Aceh, secara umum wisata halal dapat diartikan sebagai kegiatan wisata yang dikhususkan untuk memfasilitasi kebutuhan berwisata ummat Islam.

Bila dikaji lebih mendalam, peluang dalam wisata halal sangatlah besar dari sisi ekonomi. Disebutkan dalam Republika, sebuah laporan yang diterbitkan oleh World Travel Market di London pada tahun 2007 disebutkan bahwa ada potensi yang sangat besar bagi pariwisata halal dari sisi ekonomi. Menurut laporan dari Bank Indonesia (BI) menyatakan bahwa wisata halal turut mendukung pengembangan ekonomi syariah. Indonesia sebenarnya mempunyai banyak potensi wisata yang dikembangkan dalam konsep wisata halal mengingat mayoritas beragama Islam.

Berdasarkan beberapa penjelaan - penjelasan di atas, terlihat jelas bahwa Indonesia memiliki peluang yang besar untuk mengembangkan wisata halal untuk meningkatkan perekonomian. Namun demikian, menjadi penting untuk diingat bahwa potensi wisata halal di Indonesia tidak akan berkembang jika tidak dikelola dengan baik. Oleh karena itulah menjadi dasar penulis untuk membahas lebih dalam mengenai pengembangan ekonomi Indonesia berbasis wisata halal.

\section{Pariwisata Indonesia}

Sebagai negara yang besar dan mempunyai potensi wisata yang sangat beragam, Indonesia masih jauh tertinggal dari segi jumlah kedatangan wisatawan mancanegara yang masuk ke Indonesia. Indonesia mempunyai tegline wisata Wonderful Indonesia atau Pesona Indonesia untuk menarik wisatawan. Dibandingkan dengan negara - negara ASEAN, Indonesia masih berada di posisi ke-4 dari segi jumlah kunjungan wisawatan yang masuk ke Indonesia.

Tabel 1

Jumlah Kunjungan Wiatawan Mancanegara ASEAN 2018

\begin{tabular}{|c|l|c|}
\hline No & \multicolumn{1}{|c|}{ Negara } & Jumlah (Juta) \\
\hline 1. & Thailand & 38,3 \\
\hline 2. & Malaysia & 25,8 \\
\hline 3. & Singapore & 18,5 \\
\hline $\mathbf{4 .}$ & Indonesia & $\mathbf{1 5 , 8}$ \\
\hline
\end{tabular}


Pengembangan Ekonomi Indonesia Berbasis Wisata Halal

\begin{tabular}{|c|l|c|}
\hline 5. & Vietnam & 15,4 \\
\hline 6. & Philipines & 7,1 \\
\hline 7. & Cambodia & 6,2 \\
\hline 8. & Laos & 4,1 \\
\hline 9. & Myanmar & 3,6 \\
\hline 10. & Brunei Darussalam & 1,4 \\
\hline
\end{tabular}

Sumber: seasia.co

Dari gambar tabel di atas dapat dilihat bahawa di antara negara - negara ASEAN, Indonesia masih terpaut jauh dari segi jumlah kunjungan wisatawan mancanegara yang hanya mencapai 15,8 juta. Bahkan, dengan negara kecil Singapore yang mempunyai tagline wisata Your Singapotre, Indonesia masih kalah. Singapore menduduki peringkat ketiga dengan jumlah kunjungan sebanyak 18,5 juta. Malaysia dengan tagline nya Malaysia Truly Asia berada di posisi kedua dengan jumlah kunjungan 25,8 juta. Thailand masih tetap mendominasi dari segi jumlah kunjungan yaitu sebesar 38,3 juta, angka yang sangat fantastis. Angka ini mempunyai selisih lebih kurang 22,5 juta apabila dibandingkan dengan kunjungan wisata yang masuk ke Indonesia. Sepertinya tagline wisata Amazing Thailand benar-benar dapat merebut minat wisatawan untuk berkunjung ke Thailand. Meskipun Indonesia menempati urutan ke empat dari segi jumlah kunjungan, setidaknya patut mengapresiasi pihak terkait dalam hal ini Kementerian Pariwisata RI karena jumlah kunjungan wisatwan mancanegara RI yang tercatat dalam BPS mengalami kenaikan sebesar 12,58 \% dibandingkan pada tahun 2017 yang berjumlah berjumlah 14,04 juta kunjungan.

Bali, sepertinya masih menjadi sektor utama wisata andalan Indonesia. Bali masih menjadi tujuan favorit wisatawan domestik maupun mancanegara. Dalam majalah Travel+Leisure 2015 Pulau Bali dinobatkan sebagai pulau terbaik kedua di dunia dan terbaik pertama di Asia mengalahkan pulau - pulau indah di seluruh dunia. Bisa jadi karena faktor inilah pariwisata di Indonesia sulit berkembang, karena dunia luar mengenal Indonesia identik dengan Bali. Padahal, Indonesaia itu luas, beragam, masih banyak tempat - tempat wisata yang tak kalah bagus dari Bali.

Pada tahun 2019 ini, disebutkan melalui Kanal Wisata pemerintah bersama Kementerian Pariwisata RI menargetkan kunjungan wisatawan mancanegara sebanyak 20 juta. Oleh karena itu, sejak tahun 2016 pemerintah mulai mengembangkan 10 tempat wisata yang akan menjadi andalan wisata baru di Indonesia selain Bali. Adapun ke sepuluh tempat wisata yang akan dikembangkan oleh pemerintah yaitu; Danau Toba (Sumatera Utara), Tanjung Kalayang (Bangka Belitung), Mandalika (NTB), Wakatobi (Sulawesi Tenggara), Pulau Morotai (Maluku Utara), Kepulauan Seribu (Jakarta), Tanjung Lesung (Banten), Candi Borobudur (Jawa Tengah), Bromo Tengger 
Semeru (Jawa Timur), Labuan Bajo (NTT). Diharapkan dengan pengembangan sepuluh destinasi wisata baru di Indonesia, wisatawan mancanegara akan semakin banyak yang datang ke Indonesia dan tidak hanya terfokus pada Bali, sehingga target kunjungan wisatawan mancanegara akan tercapai.

\section{KAJIAN LITERATUR}

Wisata halal menurut M Battour dan M Nazari Ismail dapat didefinisikan sebagai semua objek atau tindakan yang diperbolehkan menurut ajaran Islam untuk digunakan atau dilibati oleh orang muslim dalam industri pariwisata. Secara sederhana, wisata halal dapat dikatakan sebagai konsep wisata yang tidak bertentangan dengan nilai-nilai ajaran Islam dari segala aspek baik makanan, minuman, penginapan serta objek wisata.

Sesuai dengan namanya, wisata halal dalam menjalankan peranannya tentunya mempunyai standar tersendiri yang tentunya memiliki perbedaan dengan standar wisata pada umumnya. Menurut Global Muslim Travel Index (GMTI), yang merupakan lembaga pemeringkat wisata halal dunia, menjelaskan standar wisata halal sebagai berikut:

- Destinasi ramah keluarga

- Tujuan wisata harus ramah keluarga dan anak-anak

- Keamanan bagi wisatwan muslim

- Jumlah kedatangan wisatwan muslim yang ramai

- Layanan dan fasilitas ramah bagi muslim (Muslim Friendly)

- Makanan terjamin halal

- Akses ibadah yang baik dan baik kondisinya

- Fasilitas bandara ramah bagi muslim

- Akomodasi yang memadai

- Kesadaran halal dan pemasaran destinasi

- Kemudahan komunikasi

- Jangkauan dan kesadaran kebutuhan wisatawan muslim

- Konektivitas transportasi udara

- Persyaratan visa.

\section{Tujuan Wisata Halal}

Tujuan dari wisata halal bukan semata - mata untuk mencari kesenangan jasmani saja. Akan tetapi kebahagian segi spiritual juga diperlukan. Dengan adanya wisata halal, maka kebahagiaan jasmanai dan spiritual akan tercapai. Menurut Hayu Prabowo, tujuan pembentukan wisata halal untuk menjaga tujuan wisata sesuai syariat. Selain itu, tujuan wisata halal untuk menjaga konservasi alam, menjaga keimanan wisatawan, dan menjaga tujuan wisata sesuai syariat.

\section{Pengembangan Wisata Halal Indonesia}

Pemerintah Indonesia melalui Kementerian RI terus mengembangkan potensi wisata halal di Indonesia semenjak event World Halal Tourism Summit (WHTS) tahun 2015. Dengan populasi muslim yang besar, potensi wisata halal Indonesia terbuka lebar. Negara-negara dengan mayoritas 
Pengembangan Ekonomi Indonesia Berbasis Wisata Halal

penduduk Islam menjadikan wisata halal sebagai tujuan seperti negara negara Timur Tengah, Malaysia dan Indonesia. Dengan wisata halal, wisatawan akan merasa nyaman dan tenang saat makan, minum dan beribadah. Peluang seperti ini yang seharusnya dikembangkan oleh Indonesia untuk mendongkrak kunjungan wisatawan mancanegara yang beragama Islam.

WHTS memprediksi pada tahun 2019 tidak kurang dari US\$238 M akan berputar di dunia wisata halal (di luar haji dan umrah), ini artinya pertumbuhan dunia wisata halal melejit hampir mendekati $90 \%$ lebih cepat dibandingkan dengan wisata umum dari tahun ke tahun. Lebih hebatnya, jumlah itu terus tumbuh dari waktu ke waktu. Dalam laporan World Travel Market di London pada tahun 2007, disebutkan bahwa ada potensi yang sangat besar bagi pariwisata halal dari segi ekonomi.

Mengenai pengembangan wisata halal dalam Sindo News 19 November 2018, saat ini Indonesaia memiliki 10 tujuan prioritas pengembangan pariwisata halal, antara lain; Aceh, Sumatera Barat, Riau, DKI Jakarta, Jawa Barat, DI Yogyakarta, Jawa Tengah, Jawa Timur, NTB dan Sulawesi Selatan. Dengan adanya pengembangan wisata halal dari pemerintah, diharapkan kunjungan wisatwan muslim khususnya dapat menjadikan Indonesia sebagai tujuan utama wisata mereka, sehingga perekonomian negara dan rakyat akan semakin tumbuh.

Wisata halal tidak dapat beridiri sendiri, melainkan harus saling sinergi dari semua pihak yang menjadi bagian dari keseluruhan industri halal, termasuk sektor finansial dan pembiayaan. Oleh karena itu diperlukan kerjasama untuk mendorong pengembangan wisata halal. Dengan pengembangan wisata halal, harapannya dapat mendorong perekonomian masyarakat dan negara agar menjadi lebih baik. Masyarakat akan memperoleh pengahasilan dengan berbagai pekerjaan dan penjualan/penyewaan di sekitar tempat wisata, negara akan memperoleh devisa sebagai pemasukan kekayaan negara. Dengan demikian pertumbuhan ekonomi masyarakat dan negara akan semakin meningkat.

Pengembangan wisata halal harus di dukung oleh semua pihak, pemerintah dan rakyat harus saling bersinergi untuk mengembangkan potensi wisata halal yang mempunyai prospek cerah di masa depan. Teknologi saat ini sudah semakin berkembang. Teknologi tidak dapat dilepaskan sebagai faktor kunci pengembangan wisata halal di Indonesia. Teknologi mempunyai peran yang sangat penting bagi promosi wisata halal di Indonesia. Akses media sosial, sistem pembelian dan transaksi online akan membantu mempermudah wisatawan dalam mengakses berbagai informasi yang diperlukan. Menurut Fazal Bahardeen (CEO Crescent Rating) proyeksi volume wisata halal yang diraih dari sistem pembelian online atau digital mencapai US\$ $180 \mathrm{M}$.

Pulau Lombok (NTB) yang menjadi salah satu tujuan wisata halal Indonesia menorehkan prestasi yang luar biasa. Menurut BI, Pulau yang terkenal dengan seribu masjidnya ini memilik potensi yang sangat besar untuk 
dikembangkan menjadi tujuan wisata halal. Puncaknya adalah Lombok memenangkan dua penghargaan internasional sekaligus, yakni World Halal Travel Award (WHTA) 2015 kategori World Best Halal Tourism Destination dan World Best Halal Honeymoon Destination. Dalam CNBC Indonesia pada tahun 2017, kunjungan turis di Lombok meningkat tajam hingga 50\% setelah ditetapkan menjadi destinasi wisata halal dan mendapat pengahrgaan tersebut. Pada majalah Tempo April 2019, Lombok meraih peringkat pertama kategori wisata halal terbaik di Indonesia versi Indonesia Muslim Travel Index (IMTI). Lombok menjadi yang terbaik setelah memperoleh skor 70. Peringkat kedua diikuti oleh Aceh dengan skor 66.

Aceh juga menjadi salah satu tujuan wisata halal Indonesaia. Provinsi dengan julukan Serambi Mekah ini tak luput dari torehan prestasi di dunia dalam wisata halal. Pada Serambi News tahun 2016, Aceh memperoleh penghargaan sebagai World's Best Halal Cultural Destination dalam ajang World Halal Tourism Awards 2016 yang diadakan di Abu Dhabi, Uni Emirat Arab. Memang sudah tidak mengherankan apabila Aceh merebut penghargaan ini, dikarenakan budaya dan nilai-nilai masyarakat Aceh yang kental dengan syariat Islam.

Peran Indonesia dalam kancah pengembagan wisata halal pada level internasional sepertinya sangat luar biasa. Progres peringkat Indonesia dalam wisata halal terus mengalami peningkatan setiap tahun, Lembaga pemeringkat Mastercard-Crescent merilis pemeringkatan berdasarkan standar Global Muslim Travel Index (GMTI) untuk menilai destinasi wisata halal terbaik dunia. Pada tahun 2015, Indonesia berada di peringkat 6, tahun 2016 menempati peringkat 4, tahun 2017 peringkat 3, tahun 2018 peringkat 2. Pada akhirnya di tahun 2019, Indonesia menempati posisi puncak (peringkat 1) di GMTI bersama Malaysia mengungguli 130 destinasi dari seluruh dunia, Indonesia bersama Malaysia menduduki peringkat pertama dengan memperoleh skor 78. Hal ini tak lepas dari peran besar masayarakat dan pemerintah dalam mengembangkan wisata halal. Dalam Rebublika tahun 2019 disebutkan bahwa Indonesia satu-satunya negara yang paling progresif dalam mengembangkan destinasi halal tourism.

Tabel 2

Top Halal Tourist Destinations 2019

\begin{tabular}{|c|l|c|}
\hline Rank & Negara & Score \\
\hline $\mathbf{1}$ & Indonesia & $\mathbf{7 8}$ \\
\hline 1 & Malaysia & 78 \\
\hline 3 & Turkey & 75 \\
\hline 4 & Sudi Arabia & 72 \\
\hline 5 & UAE & 71 \\
\hline 6 & Qatar & 68 \\
\hline
\end{tabular}


Pengembangan Ekonomi Indonesia Berbasis Wisata Halal

\begin{tabular}{|c|l|c|}
\hline 7 & Marocco & 67 \\
\hline 8 & Bahrain & 66 \\
\hline 8 & Oman & 66 \\
\hline 10 & Brunei & 65 \\
\hline 10 & Singapore & 65 \\
\hline 11 & Jordan & 63 \\
\hline 11 & Iran & 63 \\
\hline
\end{tabular}

Sumber: Global Muslim Travel Index (GMTI), 2019

Dari tabel di atas dapat dilihat bahwa prestasi Indonesia di kancah pengembangan wisata halal dunia sangat signifikan. Hal ini terbukti dengan posisi Indonesia yang menempati peringkat pertama di tahun 2019 dalam kategori tujuan wisata halal dunia. Prestasti ini tidak didapatkan dengan cara mudah, pemerintah melalui Kementrian Pariwisata RI terus berupaya mendorong pengembangan wisata halal di Indonesia. Setelah berjuang beberapa waktu, akhirnya Indonesia menempati peringkat pertama wisata halal dunia. Usaha keras pemerintah dan masyarakat sangat berperan dalam hal ini.

\section{SIMPULAN}

Pariwisata adalah berbagai macam kegiatan wisata dan didukung berbagai fasilitas serta layanan yang disediakan oleh masyarakat, pengusaha, Pemerintah, dan Pemerintah Daerah. UU No 10 Tahun 2009 tentang kepariwisataan menjadi payung hukum bagi pelaku di sektor pariwisata. Sektor pariwisata mempunyai peran yang besar dalam meningkatkan pemasukan devisa negara. Laporan Kementerian Pariwisata RI (Kemenpar) menyebutkan devisa menyumbang sebesar US\$ 17 M pada tahun 2018, meningkat sebesar $11,8 \%$ dibandingkan tahun sebelumnya.

Tingkat kunjungan wisatawan mancanegara ke Indonesia sepertinya masih menjadi pekerjaan rumah yang besar bagi pemerintah. Dengan menempati peringkat 4 diantara negara-negara ASEAN dalam hal jumlah kunjungan wisatwan mancanegara, rasanya tidak sebanding dengan potensi besar yang dimiliki oleh bangsa Indonesia. Jika dibandingkan dengan Thailand dengan tingkat kunjungan sebanyak 38,3 juta, jumlah kunjungan wisatawan mancanegara Indonesia masih terlalu jauh selisihnya yang hanya sebanyak 15,8 juta pada tahun 2018 .

Sektor pariwisata mulai berinovasi dengan munculnya tren wisata halal. Tren wisata halal ini muncul seiring dengan perkembangan zaman dan tuntutan masyarakat yang menginginkan wisata yang tetap dalam syariat agama seperti kemudahan dalam memperoleh makan minum halal, kemudahan beribadah. Daya tarik wisata halal sepertinya menjadi magnet tersendiri bagi pelaku wisata. 
Dalam beberapa tahun ini, Indonesia gencar mempromosikan tren wisata halal untuk menarik kunjungan wisatawan mancanegara yang mayorita berpenduduk Islam. Potensi Indonesia yang dimiliki Indonesia sangatlah besar apabila serius mengelola wisata halal tersebut. Lombok, Aceh, Sumatera Barat serta beberapa provinsi lainnya ditetapkan oleh pemerintah sebagai tujuan wisata halal di Indonesia.

Kinerja Indonesia yang terus mengelaola wisata halal akhirnya berbuah manis. April 2019, akhirnya Indonesia ditetapkan peringkat pertama sebagai tujuan wisata halal terbaik di dunia bersama dengan Malaysia. Tentunya ini merupakan hasil kerja keras dari masyarakat, pemerintah serta pelaku wisata di Indonesia. Harapannya dengan pengembangan wista halal ini dapat memperkuat perekonomian masyarakat dan negara Indonesia.

\section{DAFTAR PUSTAKA}

Badan Pusat Statistik (BPS)

Bank Indonesia, Memperkuat Perekonomian Indonesia melalui Wisata Halal,15 Oktober 2018.

BPS dalam Kontan, BPS Mencatat Kunjungan Wisatawan Mancanegara 2018 Tumbuh $12,58 \%$.

CNBC Indonesia, Lombok Destinasi wisata Halal Tervavorit di Dunia, 12 April 2018.

Dinas Kebudayaan dan Pariwisata Aceh, Sekilas Tentang Wisata Halal, 6 September 2016.

Fazal Bahardeen (CEO CrescentRating) dalam peluncuran Global Muslim Travel Index 2019. Republika, Teknologi Bantu Pengembangan Wisata Halal, 9 April 2019.

Global Travel Muslim Index 2018.

Go Property, Indonesia Surga Wisata Halal Dunia, 14 Februari 2017.

Hayu Prabowo (Ketua Lembaga Pemulihan Lingkungan Hidup dan SDA MUI), MUI: Destinasi Wisata Halal Jaga Tujuan Wisata Sesuai Syariat, 11 Oktober 2018.

Kanal Wisata, 10 Tempat Wisata Indonesaia Yang Akan Dikembangkan, 6 November 2016.

Kementerian Pariwisata RI, Data Kunjungan Wisatawan Mancanegara Januari

- Desember 2018. 
Pengembangan Ekonomi Indonesia Berbasis Wisata Halal

Liputan 6. Genjot Pariwisata, Menpar Targetkan 20 Juta Turis Asing pada 2019.

M.Battour dan M Nazari Ismail dalam Wisata Peradaban, Pengertian dan Indikator Wisata Halal.

Maghfira Maulidia Putri, Sharianews, Potensi Indonesia Menjadi Surga Wisata

Halal Dunia, 29 Januari 2019.

Republika, Menangkap Teren Wisata Halal, 25 September 2016,

$\underset{2019}{ }$, Pariwisata Halal Indonesia Paling Progresif di Kancah Global, 9 April

Seasia, Good News from Southeast Asia World's Top Halal Tourist Destinations 2019 Ranked, https://seasia.co/2019/04/10/world-s-tophalal-tourist-destinations-2019-ranked.

RANKED: International Tourist Arrivals In Southeast Asia Countries 2018, https://seasia.co/2019/03/15/internationaltourist-arrivals-in-southeast-asia-countries-2018.

Serambi News, Aceh Terima Piagam wisata Halal Dunia, 22 Desember 2016.

SindoNews, Prospek Wisata Halal Indonesia, 19 November 2018.

Tempo, Lombok Memiliki Wisata Halal Terbaik di Indonesia versi IMTI, 10 April 2019.

UU No 10 Tahun 2009 Pasal 1 ayat 1 tentang Kepariwisataan. 
Fitrianto

Halaman ini sengaja dikosongkan 